\title{
Discussion of Strengthening Strategies of Financial Accounting Informa- tion Management on the Basis of Characteristics of Financial Accounting Information
}

\author{
Wang Ning ${ }^{1, *}$, Jian Ming ${ }^{2}$ and Wang $\mathrm{Yu}^{3}$ \\ ${ }^{I}$ Computer Science Department, Northeast Petroleum University at Qinhuangdao, Qinhuangdao, 066004, Hebei, China; \\ ${ }^{2}$ School of Statistics, Renmin University of China, Beijing, 100872, China; ${ }^{3}$ Beijing Haidian Branch, Tarena Software \\ Technology Co., LTD. (Hangzhou), Beijing, 100098, China
}

\begin{abstract}
Financial accounting information management is an important part of business management of chemical enterprises and it plays an important role in the enterprise development. To solve problems of low-quality financial accounting information and high financial risks and so on, taking the chemical enterprise as an example and analyzing the characteristics of financial accounting information, this paper discusses the problems in the financial accounting information management of chemical enterprises, and puts forward corresponding solutions. From the aspects of transparency of financial accounting information, auditing, monitoring and personnel, this paper puts forward the management strategies to improve the quality of financial accounting information, through the informationized tools, high-quality personnel, scientific workflow and close monitoring of financial accounting information flow.
\end{abstract}

Keywords: Characteristics of financial accounting information, financial accounting information management, strengthen strategies.

\section{INTRODUCTION}

Rapid economic development accompanies with updating of information technology. The traditional financial accounting management of enterprises also develops into information management [1-4], with continuous development and improvement. As an important part in modern business management, the financial accounting information management can greatly improve work efficiency of financial personnel, and expand the area of financial and accounting. The financial accounting information management brings much convenience and benefits to the enterprise [5-7]. However, there still exist many defects and problems in the financial accounting information management. Only these problems are solved, can financial accounting information management be strengthened.

\section{THEORETICAL REVIEW OF CHARACTERISTICS OF FINANCIAL ACCOUNTING INFORMATION}

For the enterprise under current development state of market economy, their operational and managerial activities might need the guidance of financial accounting information. But first, it needs to determine if the financial accounting information is valid and useful, which can be conducted from two aspects. The first aspect is the function. Firstly, financial accounting information must be relevant, because the managers would more focus on some information when they utilize the information. Secondly, financial accounting information must be verifiable; same value and conclusion can be obtained according to same information and vouchers, although the information is utilized by different person. Thirdly, financial accounting information must be impartial; the information must be real and reliable and the error caused by personal factors cannot exist [8-10]. Finally, financial accounting information must be measurable; this is the basic characteristic of financial accounting information and it is for data statistics after the enterprise obtains the information and then carries out management activities.

The second aspect is the structure. Financial accounting information is the joint name of kinds of output data in the financial accounting system and its structure and technology have different characteristics. Firstly, no matter which kind of data it is, financial accounting information has related standards of output data. For example, vouchers and bookkeeping notes can be collected and form corresponding financial accounting information. Secondly, financial accounting information also has certain standards of input data. All original data and vouchers, which are input into the financial accounting information system, are regarded as the financial accounting information. Both input data and output data are to intuitively reflect the operational and managerial results and financial situation of the enterprise in some period, which are important data for business operation and management.

Generally, chemical enterprises will set the financial accounting goal before operation and production activities, and financial accounting information influences the goal setting to a certain extent. Therefore, the quality characteristics of 
financial accounting information become the characteristics of decision usefulness of accounting information, as shown in Fig. (1).

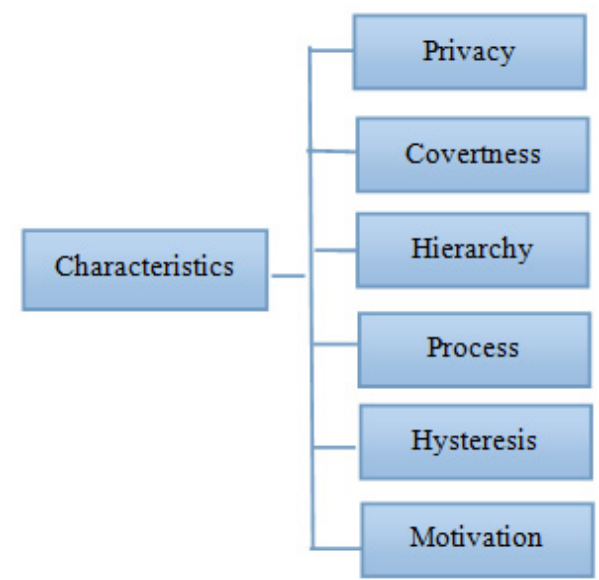

Fig. (1). Characteristics of financial accounting information.

\subsection{Privacy}

Financial accounting information belongs to the enterprise and is the public property, while it is characterized with sociality and privacy due to its special generation environment and methods.

\subsection{Covertness}

For example, the cash information is private and convert.

\subsection{Hierarchy}

Hierarchy mainly features the principal-agent relationship between the owner and the operator of the enterprise. But in this relationship, inequality of financial accounting information will occur.

\subsection{Process}

It needs a process to generate financial accounting information while the time for generation is different.

\subsection{Hysteresis}

Financial accounting information is characterized with certain hysteresis. And this kind of time difference could not completely be avoided. We can only try to shorten the time from information processing to information application during the process of accounting computerization.

\subsection{Motivation}

Seen from current development state of chemical enterprises in the market economy, to better protect the benefits of medium and small investors and shareholders of listed chemical enterprises, it is required that these listed enterprises must disclosure interim financial statement and annual financial statement. This makes the enterprises motivated to disclosure accounting information.

Just because financial accounting information of chemical enterprises is characterized with covertness, hysteresis, hierarchy, motivation, process and privacy, and the quality of financial accounting information is not good, the enterprises face financial risks and their sound development is influenced. It is necessary to correctly identify financial risks and take right measures. Taking some chemical enterprise as an example, Meng Xuning analyzes the evaluation system of financial risks, determines the weight of each evaluation index, and verify the validity of the weight by calculating the proper value and proper vector of the matrix. The formula of proper value is $\lambda_{\max }=\frac{1}{n} \sum_{i=1}^{4} \frac{(A \omega)_{i}}{\omega_{i}}$. The proper value of matrix A is calculated. And then check Mean Random Consistency Index in same order to get the verification index and further determine if matrix $\mathrm{A}$ is valid.

\section{DEFECTS AND PROBLEMS IN FINANCIAL AC- COUNTING INFORMATION MANAGEMENT}

\subsection{Untrue Information}

The advancement of information technology helps modern chemical enterprises achieve informationized financial accounting management. In contrast with traditional management, informationized management helps chemical enterprises collect true and accurate information more quickly and then control and manage production distribution and cash flow more quickly. But in many Chinese enterprises, due to various reasons, especially the interests, financial accounting information is non-transparent and not symmetric and integrated enough, which causes that the collected information is generally distorted and the accuracy of accounting cannot be ensured. In nearly $80 \%$ of enterprises in China, there exists distortion of financial accounting information.

\subsection{Inadequate Supervision}

Inadequate supervision on financial accounting exists in many enterprises. Chemical enterprises are no exception. And inadequate supervision will result in more embezzlements, corruptions and capital transfers. Quite a number of enterprises in China are not in the constraint of the decisionmaking mechanism when it comes to many major issues, such as major investment. Then the situation that individuals make decisions for the enterprise occurs, which causes that fund flow and expected controls are separate. Now many enterprises have their subsidiaries. But many parent enterprises only know the business condition of the subsidiaries, but don't know the capital flow and movement in detail. Many enterprises are unable to make ends meet. They borrow money to pay back their old debts. Such finance is very unstable and very risky, which is harmful to have sound and stable development of enterprises. In some enterprises, when managers of financial accounting handle the accounts, accounting decides financial accounting management, and the leader's individual will decides accounting. That makes financial accounting supervision just a form and fail to exert its real function.

\subsection{Low Capital Usage Efficiency}

Capital is an important element for production and development of the enterprise. An enterprise without good capital flow could not have sound and long-term development. Now the market competitiveness is very fierce. If the enterprise wants to develop and run well, it has to take capi- 
tal as the core and achieve the best usage efficiency. Many enterprises don't pay enough attention to capital usage, resulting in low usage efficiency. Either the opening of accounts of subsidiaries or the capital management of parent enterprises is in disorder. The investment decision is made casually. Then the enterprises' own ability cannot catch up with the development goal, resulting in the decline of business ability and credit.

\subsection{Inadequate Comprehensive Quality of Financial Ac- counting Personnel}

Now the comprehensive quality of financial accounting personnel is also an important factor influencing financial accounting information management. On the one hand, chemical industry is not newly-emerged industry. The traditional enterprise wants to change old management mode to information management mode, but financial accounting personnel are not always to adapt themselves to the changes, and their professional skills will be not enough. On the other hand, driven by economic benefits and influenced by political and economic management system, it is difficult to keep the authenticity and objectivity of accounting activities. Above two aspects will lower the quality of accounting information. There are mainly below factors causing the distortion of financial accounting information. Firstly, due to weak legal consciousness and legal sense, the personnel in charge of relevant work in the enterprise are driven by benefits easily. Secondly, financial accounting activity lacks corresponding supervision and constraint, resulting in rampant fraud. Lastly, financial personnel have no enough work ethics and fail to form a good sense of law and discipline.

\subsection{The Management's Inadequate Understanding of Financial Accounting Information Management}

As the leaders and organizers of an enterprise's management, the managers firstly should strengthen their understanding of financial accounting information management and realize that it is an important part of business management, and then have staff pay attention to it in their daily work and form unified understanding. However, the current situation is that the management in many chemical enterprises has certain misunderstanding of financial accounting information management and thinks that disclosure of financial accounting information equals is equivalent to disclosure of the enterprise information. And no specially-assigned person is in charge of related work. Then the financial accounting information management could not make progress. Therefore, to strengthen the management's understanding of financial accounting information is an effective measure to promote development of chemical enterprises.

\section{STRENGTHEN STRATEGIES OF FINANCIAL AC- COUNTING INFORMATION MANAGEMENT OF CHEMICAL ENTERPRISES BASED ON THE CHAR- ACTERISTICS OF FINANCIAL ACCOUNTING IN- FORMATION}

\subsection{Enhance Transparency and Publicity of Financial Accounting Information}

The business benefits are not owned by an individual, but shared by many persons. Different enterprises have different requirements on transparency of financial accounting information, such as frequency and ways and scope of disclosure, but the purpose of enhancing transparency of financial accounting information won't change. To complete related work of financial accounting information, capital management and accounting is the premise to ensure the enhancement of transparency of financial accounting information of enterprises. Meanwhile, the internal control should be implemented, such as performance appraisal and accounting informatization. If accounting is not informationized, the enterprise could not have a deep understanding of actual situation of basic accounting units and might be restrained by basic accounting units. Therefore, daily financial supervision can be completed from below aspects, as shown in Fig. (2). Firstly, obtain accurate financial accounting information timely, and know about relatively complete and real business accomplishments and financial situation of the subsidiaries. Secondly, strengthen financial supervision from all aspects to realize supervision on accounting, capital and assets operation of the subsidiaries. Thirdly, conduct centralized financial management. Closed and stationary business management cannot meet the demand of quick and normal development of enterprises. Only realize dynamic, informationized, standardized and transparent business management, can financial management and financial supervision be completed well and can the centralized financial management fit into the enterprise.

\subsection{Strengthen Financial Auditing}

A specialized auditing department should be set up in the enterprise to complete business auditing and achieve daily financial supervision, combining periodic check and temporary spot check, and implementing incentives and disincentives for the auditing results. Meanwhile, to continuously improve quality management of accounting activities and strengthen internal auditing supervision, the enterprise need establish financial post rotation system and keep it improved. The quality of financial accounting information management can be improved by conducting comprehensive assessment on professional accounting skills and assessment on the quality of financial accounting information. The violation of laws and disciplines should be strictly prevented in the enterprise.

In the mean time, we can also establish a financial supervision platform to directly and concentratedly reflect contents of daily financial supervision and realize unification and timeliness of financial supervision. The details are as shown in Fig. (3).

\subsection{Strengthen Identification and Handling of Financial Risks}

To effectively improve the level of financial accounting information management of chemical enterprises, reduce financial risks and promote substantial development of enterprises, the enterprises also must see and identify financial risks by use of scientific methods and take effective measures to prevent and handle risks. Because variables of financial accounting information are fuzzy and uncertain, the risk research is usually conducted by adopting fuzzy analytic hierarchy process (FAHP). FAHP is actually the extension of analytic hierarchy process (AHP) under fuzzy conditions. 


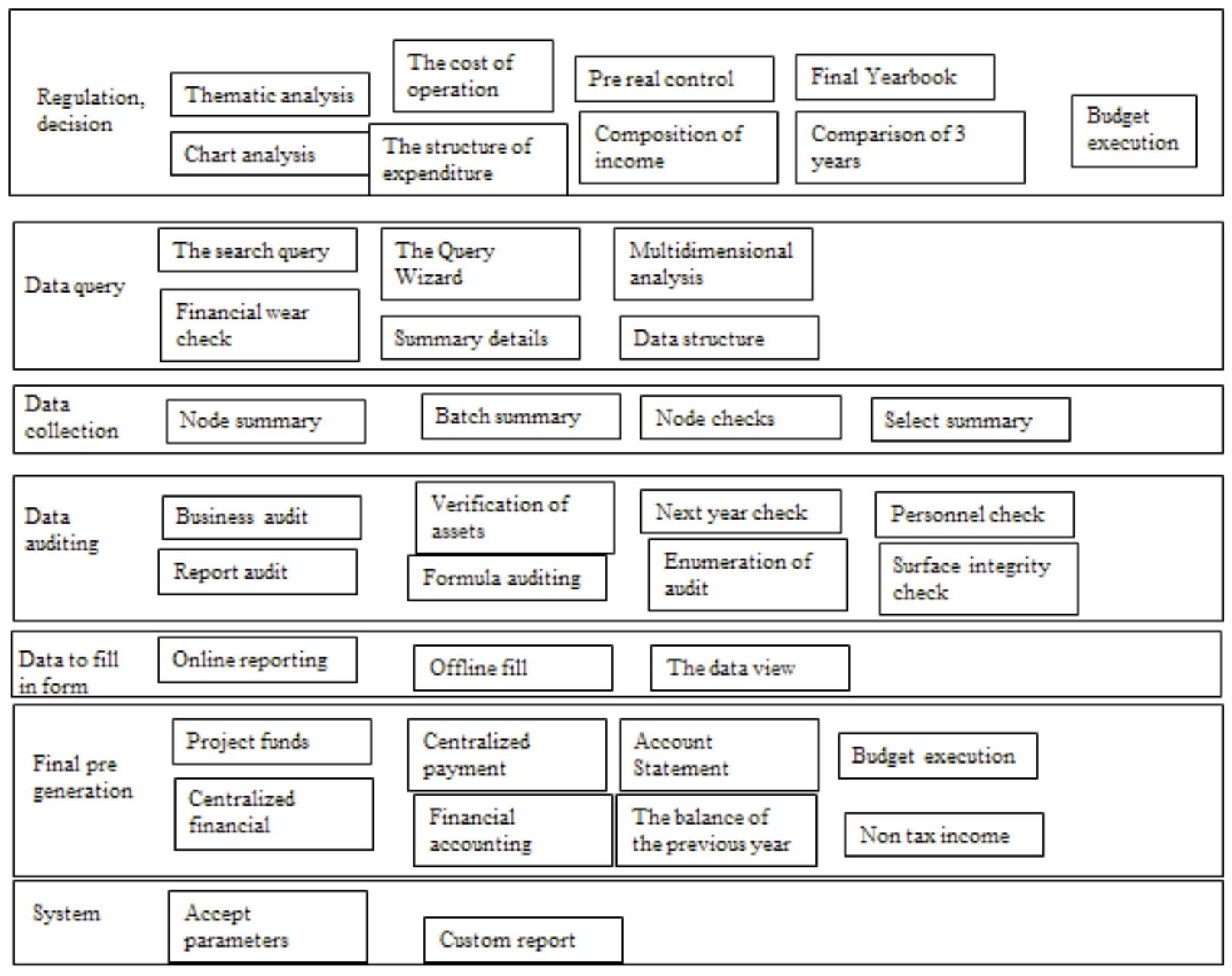

Fig. (2). Enhance transparency of financial accounting information by use of information management system.

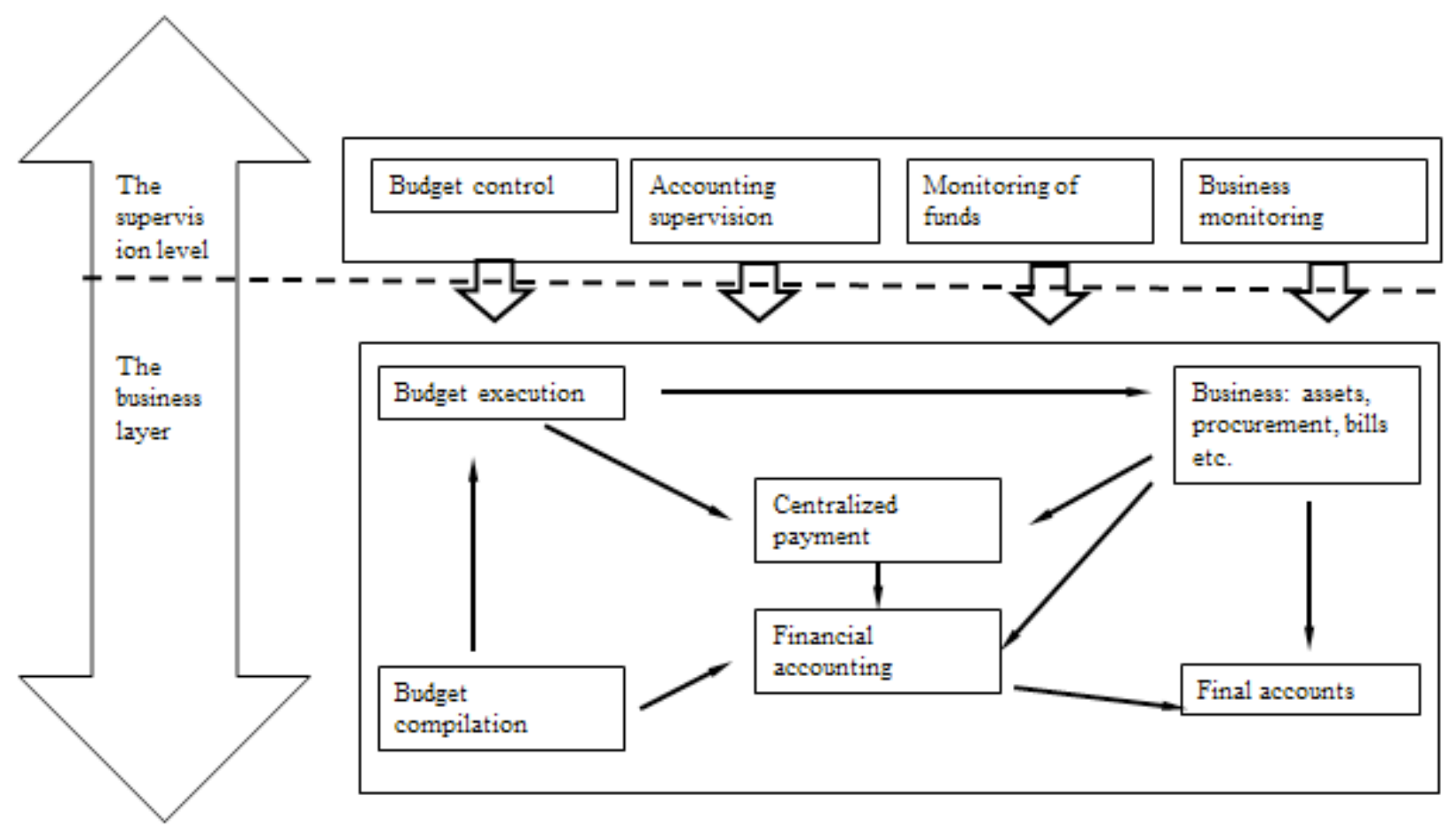

Fig. (3). Schematic diagram of financial supervision. 
That is, utilize triangle fuzzy values to establish the judgment matrix, avoid subjective judgment and make financial decisions more reasonable. In the following, objective weight determination is utilized to establish the judgment matrix. Fuzzy values and calculation of fuzzy values are mainly included.

\subsubsection{Fuzzy Values}

Set $M$ as a triangle fuzzy value in the set $\mathrm{R}$ of real numbers. $\mathrm{R} \in[0,1] . \mathrm{M}$ is subordinate to the function $(\mathrm{x})$. Then,

$$
u(x)=\left\{\begin{array}{l}
\frac{x-a}{m-a}, a \leq x \leq m \\
\frac{b-x}{b-m}, m \leq x \leq b
\end{array}, \text { where } 1 \leq \mathrm{m} \leq \mathrm{u} . \text { We call } \mathrm{M}\right.
$$

the triangle fuzzy value and consider $\mathrm{m}$ as the core of $\mathrm{M}$, and then $a$ and $b$ are lower limit and upper limit of $M$ respectively. Therefore, we can simply record the triangle fuzzy value as $\mathrm{M}=(1, \mathrm{~m}, \mathrm{u})$.

\subsubsection{Calculation}

Assume that $\mathrm{M}_{1}=\left(\mathrm{l}_{1}, \mathrm{~m}_{1}, \mathrm{u}_{1}\right)$ and $\mathrm{M}_{2}=\left(\mathrm{l}_{2}, \mathrm{~m}_{2}, \mathrm{u}_{2}\right)$ are two fuzzy values, and that the weight of various elements is $\mathrm{Si}$ $(\mathrm{i}=1,2,3 \ldots, \mathrm{n})$. Set $\mathrm{X}=\left\{\mathrm{x}_{1}, \mathrm{x}_{2}, \mathrm{x}_{3} \ldots, \mathrm{x}_{\mathrm{n}}\right\}$ as the object set and $\mathrm{U}=\left\{\mathrm{u}_{1}, \mathrm{u}_{2}, \mathrm{u}_{3} \ldots, \mathrm{u}_{\mathrm{n}}\right\}$ as the target set.

If the weight of the $i_{\text {th }}$ element is higher than that of the $j_{\text {th }}$ element, then the degree of possibility can be recorded as:

$$
\vee\left(M_{1} \geq M_{2}\right)=\left\{\begin{array}{cc}
1 & m_{1} \geq m_{2} \\
\frac{l_{2}-u_{1}}{\left(m_{1}-u_{1}\right)-\left(m_{2}-l_{2}\right)} & m_{1} \nwarrow_{2}, l_{2} \nwarrow_{1} \\
0 &
\end{array}\right.
$$

In the calculation of different fuzzy judgment matrixes, calculate the possibility that the $i_{\text {th }}$ element $A_{i}$ is more important than other elements in the same hierarchy. The formula is: $\quad d /\left(A_{i}\right)=\min \vee\left(S_{i} \geq S_{k}\right), k=1,2,3 \quad, n, k \neq i$. Thus, we can calculate the weight vectors: $\omega=\left(d\left(A_{1}\right), d\left(A_{2}\right), \cdots, d\left(A_{n}\right)\right)^{T}$. The synthetic ordering vector of all elements in the $\mathrm{N}_{\text {th }}$ hierarchy against total target and the ordering vector of all elements in the $\mathrm{N}-1_{\text {th }}$ hierarchy against total target $\times$ the single ordering of all elements in the $\mathrm{N}_{\text {th }}$ hierarchy against all elements in the $\mathrm{N}-1_{\text {th }}$ hierarchy. The result calculated is the comprehensive score of the elements in the $\mathrm{N}_{\text {th }}$ hierarchy against total target. According to the comprehensive score, we can evaluate the influence of each financial variable on the total financial target of the enterprise.

\subsection{Improve Capital Usage Efficiency Continuously}

To improve capital usage efficiency and strengthen capital management, the enterprise should strengthen financial accounting information management, implement strict finan- cial control, develop a rigorous system for daily financial management and check the implementation periodically to maximize the effect of internal restriction mechanism. And those physical properties should be recorded and taken care of, as well as be checked periodically and verified with the records. This method is helpful for rapid development of the enterprise, and also can ensure safety of the enterprise's property as possible as it can.

\subsection{Improve Comprehensive Quality of Financial Per- sonnel}

The comprehensive quality of financial personnel has a direct influence on and is proportional to the quality of financial accounting work. The enterprise should build a financial team with professional skills, mature ideological and political thinking, and sound mind and body. Starting with ideological and political qualities of financial staff, improve their professional skills by firming ideological foundation and combining kinds of staff trainings. Meanwhile, arrange reasonable posts to in-service financial personnel and try to make the best use of their qualifications.

\section{CONCLUSION}

As an important part of information of socialist market economy, financial accounting information can reflect kinds of conditions of modern enterprises during some period, such as asset changes and development. It provides numerous reliable data to the enterprises and is important reference for making economic decisions. Good management of financial accounting information helps reduce financial risks for the enterprises and promote substantial development. Therefore, in business management, we should pay attention to financial accounting management. Starting with the characteristics of financial accounting information, strengthen financial accounting information management and better help chemical enterprises achieve all-round development and rapid progress. Starting with the characteristics, this paper gives a detailed analysis of problems in financial accounting information management of chemical enterprises, and puts forward some suggestions to help chemical enterprises strengthen financial accounting management and reduce risks. It has certain guiding significance.

\section{CONFLICT OF INTEREST}

The authors confirm that this article content has no conflict of interest.

\section{ACKNOWLEDGEMENTS}

This work is supported by Heilongjiang province education scientific planning project" Research and practice of college students' entrepreneurship education base on schoolenterprise cooperation "(No. ZJC1214002), Hebei province natural science fund project "research on port supply chain management key common problems (No. G2015203378) and qinhuangdao soft science research plan project" port two-way integration research on the structure analysis and optimization of the supply chain (No. 201301B044), and Daqing city philosophy and social sciences planning research project in 2015"research on promotion energy con- 
servation and emissions reduction and speeding up the construction of green low-carbon transport environment in daqing city."

\section{REFERENCES}

[1] P. Armstrong, "The rise of accounting controls in British capitalist enterprises," Accounting, Organizations and Society, vol. 12, no. 5, pp. 415-436, 1987.

[2] N. G. O'Connor, W. C. Chee, and A. Wu, "The adoption of "Western management accounting/controls in China's state-owned enterprises during economic transition," Accounting, Organizations and Society, vol. 29, no. 3, pp. 349-375, 2004

[3] J. Mouritsen, A. Hansen, and C.Ø. Hansen, "Inter-organizational controls and organizational competencies: episodes around target cost management/functional analysis and open book accounting." Management Accounting Research, vol. 12, no. 2, pp. 221-244, 2001.

[4] L. Kurunmäki, "A hybrid profession - the acquisition of management accounting expertise by medical professionals," Accounting, Organizations and Society, vol. 29, no. 3, pp. 327-347, 2004.
[5] R. M. Bushman, and J. S. Abbie, "Financial accounting information and corporate governance," Journal of accounting and Economics, vol. 32, no. 1, pp. 237-333, 2001.

[6] R. Bushman, Q. Chen, E. Engel, and A. Smith, "Financial accounting information, organizational complexity and corporate governance systems," Journal of Accounting and Economics, vol. 37, no. 2, pp. 167-201, 2004

[7] S. E. Bonner, R. Hastie, G.B. Sprinkle, and S.M. Young, "A review of the effects of financial incentives on performance in laboratory tasks: Implications for management accounting," Journal of Management Accounting Research, vol. 12, no. 1, pp. 19-64, 2000.

[8] N. Marriott, and M. Pru, "Professional accountants and the development of a management accounting service for the small firm: barriers and possibilities," Management Accounting Research, vol. 11, no. 4, pp. 475-492, 2000.

[9] S. E. Perry, and H. W. Thomas, "Earnings management preceding management buyout offers," Journal of Accounting and Economics, vol. 18 , no. 2 , pp. 157-179, 1994.

[10] R. G. Sloan, "Financial accounting and corporate governance: a discussion," Journal of Accounting and Economics, vol. 32, no. 1, pp. 335-347, 2001.

Received: June 10, 2015

Revised: July 29, 2015

Accepted: August 15, 2015

(C) Ning et al.; Licensee Bentham Open.

This is an open access article licensed under the terms of the (https://creativecommons.org/licenses/by/4.0/legalcode), which permits unrestricted, noncommercial use, distribution and reproduction in any medium, provided the work is properly cited. 